\title{
COD and nutrient removal from urban effluent by Desmodesmus subspicatus
}

\section{Remoção de DQO e nutrientes de efluente doméstico por Desmodesmus subspicatus}

\author{
Reinaldo Gaspar Bastos ${ }^{1}$; Vanessa Ribeiro Urbano ${ }^{2}$; Fabiane Karen Godoy ${ }^{3}$; \\ Luiz Felipe Arjonilla de Mattos ${ }^{4}$; Claudinei Fonseca Souza ${ }^{5}$
}

\begin{abstract}
The aim of this research was to evaluate the heterotrophic growth and removal of COD and nutrients (nitrogen and phosphorus) of green microalgae Desmodesmus subspicatus from domestic wastewater collected in pilot plant of treatment and water reuse of the CCA/UFSCar. The results showed maximum specific growth rates of $0.084 \mathrm{~h}^{-1}$, with biomass concentrations of $1000 \mathrm{mg} \mathrm{L}^{-1}$ in 24 hours of the experiment. Due to the chemical content of the sterilized effluent, both the organic matter as nitrogen are limiting to microbial growth. However, for COD above $200 \mathrm{mg} \mathrm{L}^{-1}$, there was a high conversion of organic matter into biomass. These results suggest the feasibility of microalgae in one of the stages of suitability for agricultural reuse of domestic wastewater.
\end{abstract}

Keywords: Nutrient removal. Microalgae. Urban wastewater.

\section{Resumo}

O trabalho teve como objetivos avaliar o crescimento heterotrófico e potencial de remoção de DQO e nutrientes (nitrogênio e fósforo) da microalga clorofícea Desmodesmus subspicatus em esgoto doméstico coletado em estação piloto de tratamento e reúso de água do CCA/UFSCar. Os resultados indicaram velocidades específicas de crescimento máximas de $0,084 \mathrm{~h}^{-1}$, com concentrações de biomassa de $1000 \mathrm{mg} \mathrm{L}^{-1}$ em 24 horas de cultivo. Devido à composição do efluente esterilizado, tanto a quantidade de matéria orgânica como nitrogênio são limitantes para o crescimento microbiano. Entretanto, para valores de DQO acima de $200 \mathrm{mg}$ $\mathrm{L}^{-1}$, houve uma elevada conversão de matéria orgânica do efluente em biomassa. Estes resultados sugerem a viabilidade de aplicação desta microalga para produção de biomassa e remoção de parte dos nutrientes e matéria orgânica deste efluente, podendo ser considerada como uma das etapas de adequação para reúso agrícola de esgoto doméstico.

Palavras-chave: Remoção de nutrientes. Microalgas. Efluentes domésticos.

\footnotetext{
${ }^{1}$ Prof. Dr., Dpto. de Tecnologia Agroindustrial e Sócio-Economia Rural, UFSCar, SP, Brasil; E-mail: reinaldo.bastos@ufscar.br

2 Mestranda, Programa de Pós-Graduação em Agricultura e Ambiente, UFSCar, SP, Brasil; E-mail: nessaru@ gmail.com

${ }^{3}$ Mestranda, Programa de Pós-Graduação em Agricultura e Ambiente, UFSCar, SP, Brasil; E-mail: godoy.fabiane@ gmail.com

${ }^{4}$ Mestrando, Programa de Pós-Graduação em Agricultura e Ambiente, UFSCar, SP, Brasil; E-mail: arjonilla.lf@ hotmail.com

${ }^{5}$ Prof. Dr., Depto. de Recursos Naturais e Proteção Ambiental, UFSCar, SP, Brasil; E-mail: cfsouza@ufscar.br
} 


\section{Introduction}

The use of microalgae in the wastewater treatment has been studied as an alternative to conventional decontamination processes. These processes have as great advantage the use of the biomass generated in the production of single-cell protein, cell compounds as pigments or the production of biodiesel through the transesterification of the microalgal oil. In this sense, different species of the Chlorophyte microalgae Desmodesmus (Scenedesmus) have been cultivated as free cells and immobilized from industrial, urban and synthetic wastewater (MARTINÉZ et al., 2000; WU et al., 2012; MATTOS; BASTOS, 2015; SILVA et al., 2017). This green microalga has presented high cellular viability in domestic wastewater, tolerating variations in temperature and $\mathrm{pH}$. Martínez et al. (2000) evaluated the cultivation of Scenedesmus obliquus microalgae in effluent collected from secondary treatment in the city of Granada, Spain. These authors report specific maximum growth rates around $0.0438 \mathrm{~h}^{-1}$ at $30^{\circ} \mathrm{C}$, with practically deletion of total phosphorus and nitrogen. Xin et al. (2010) evaluated the cultivation of Scenedesmus sp. LX1 in different nitrogen sources, obtaining nutrient removal near $90 \%$ using nitrate or urea. In this same study, the authors obtained the maximum specific growth rate (0.034h-1) with ammonia, despite the inhibition caused by the reduction of $\mathrm{pH}$. Bastos et al. (2012a) evaluated the cultivation of the microalgae Desmodesmus subspicatus in vinasse from sugarcane processing, showing growth at a maximum specific rate of $0.096 \mathrm{~h}-1$, with biomass productivity around $1.8 \mathrm{~g} \mathrm{~L}^{-1} \mathrm{~h}^{-1}$. According these authors, highlight that these results are promising for the generation of value-added biomass in terms of lipids and proteins from agro industrial wastewater.

Although photosynthesis is a preferential metabolism, several microalgae and cyanobacteria strains can grow under mixotrophic and heterotrophic conditions depending on the culture conditions, i.e., growth by organic compounds. This type of process presents considerable economic advantages when compared to the autotrophic crops, besides a superior biomass production and consequent consumption of substrates. In this sense, the treatment of wastewater through the heterotrophic culture of free and immobilized cells of microalgae and cyanobacteria is promising both for the removal of nutrients and soluble organic matter (BASTOS et al., 2004; PEREZ-GARCIA et al., 2011). The heterotrophic culture of Chlorella vulgaris in municipal wastewater presented the best results in supplemented acetate medium (PEREZ-GARCIA; BASHAN; PUENTE, 2011). The au- thors demonstrated the feasibility of conducting cultures with high cell concentration ( $>10^{7}$ cells per $\mathrm{mL}$ ), ten times higher than that usually occurs in autotrophic processes, with similar removal of ammonia. These metabolic differences could be explained by the higher yield of ATP in biomass (19.3 $\mathrm{g}$ per mmol) under heterotrophic aerobic conditions. The use of high concentrations of biomass generally increases the success of biological treatment of wastewater. This microalga is cited in the literature as efficient in the removal of nitrogen when compared to phosphorus also under mixotrophic conditions (ASLAN; KAPDAN, 2006).

Due to high turbidity of industrial and urban wastewater, it would be recommended to use microorganisms capable of growth through consumption or assimilation of organic molecules without light availability with carbon and nutrients consumption. Bhatnagar et al. (2011) reported a mixotrophic growth of Chlamydomonas globosa, Chlorella minutissima and Scenedesmus bijuga from glucose, sucrose, sodium acetate, methanol, glycerol, urban and agroindustrial effluents. Wu et al. (2012) evaluated the growth of Clamydomonas sp. TAI-2 and Desmodesmus sp. TAI-1 in photobioreactor using effluent from the Taichung Industrial Park, Taiwan. The best results indicated depletion of ammonia and nitrate and 33\% removal of phosphorus, generating a biomass with $18.4 \%$ of lipid content, with promising result for the subsequent production of microalgal biodiesel. Devi, Subhash and Mohan (2012) studied the heterotrophic culture of microalgae in urban effluent supplemented with different nutrients and glucose, presenting high biomass production and nutrient removal. The authors suggest the production of microalgae of the genus Chlorella and Scenedesmus from wastewater for the use of biomass to obtain biodiesel.

Domestic and municipal effluents consists a complex mixture of soluble and suspended solids. Most of these effluents present soluble organic matter even after secondary biological treatment, suggesting the presence of carbon sources available for bacteria but difficult to assimilate by microalgae (PEREZ-GARCIA et al., 2011). However, even if no organic matter and nutrient removals comparable to conventional effluent treatment processes were obtained, the cultivation would lead to the generation of biomass with add-value and would suit the composition of the water for agricultural reuse.

In this sense, the Center of Agricultural Sciences (CCA) of the Federal University of São Carlos (UFSCar) in Araras, São Paulo, Brazil, has been set up researches on agricultural reuse of urban wastewater generated in the university Campus. The agricultural reuse of water is 
a technology already applied in several countries and is indicated as one of the possible solutions to the problems of water scarcity and to combat the pollution of rivers and springs, increasing the availability of clean water for human consumption. Agricultural reuse of domestic effluents can be an alternative considering its content in organic matter, nitrogen, phosphorus and other nutrients, which are essential for plant development. CCA has a pilot wastewater treatment and reuse consisting of a septic tank unit, an upflow anaerobic filter, a microalgae system, followed macrophytes bed for final suitability of the effluent. The treated effluent has been evaluated for soil availability, quality and applicability in lettuce and radish crops (MENDONÇA et al., 2013; MENDES et al., 2013). In addition, it is important to study the development of microalgae in this effluent with partial removal of nitrogen and phosphorus with microalgal biomass add-value and posterior agricultural reuse.

Thus, the aim of this research was evaluated the potential of COD, nitrogen and phosphorus removal from urban wastewater of CCA/UFSCar by the Chlorophyta microalgae Desmodesmus subspicatus.

\section{Materials and methods}

Desmodesmus subspicatus was maintained in the Laboratory of Applied Microbiology of CCA/UFSCar from BG11 medium (RIPPKA et al., 1979), using an initial concentration of inoculum of approximately $500 \mathrm{mg}$ $\mathrm{L}^{-1}$ for the wastewater experiments, corresponds to $10^{6}$ cells per $\mathrm{mL}$. Biomass was separation by centrifugation for 5 minutes at $3000 \mathrm{rpm}$ in ELCESA ${ }^{\circledR}$ II $206 \mathrm{BL}$.

The wastewater collected in the output of septic tank of pilot treatment and water reuse station of the CCA/UFSCar (OLIVEIRA; BASTOS; SOUZA, 2019). The samples were sterilized and homogenized with the microalgae inoculum in $125 \mathrm{~mL}$ Erlenmeyers. The flasks were protected of light to maintain heterotrophic metabolism and experiments were set up in an orbital shaker incubator (TECNAL ${ }^{\circledR}$ TC-420) at $150 \mathrm{rpm}$. Urban wastewater sample used had pH 7.1, chemical oxygen demand (COD) of $406 \mathrm{mg} \mathrm{L}^{-1}$, total nitrogen (NT) of 332 $\mathrm{mg} \mathrm{L}^{-1}$ and phosphorus (P) $15.4 \mathrm{mg} \mathrm{L}^{-1}$. Experiments were monitored every 3 hours with determination of the cell concentration profiles and substrates in 30 hours.

Biomass content was determined by gravimetric method after known volume filtration of the sampled suspension during the $0.22 \mathrm{~m}$ filter cultures and drying at $105^{\circ} \mathrm{C}$ for 24 hours (APHA, 2005). From this, growth curves were obtained and the maximum specific growth rates were estimated. COD was determined by the closed reflux colorimetric method, and the digested solution $\left(\mathrm{H}_{2} \mathrm{SO}_{4}+\mathrm{K}_{2} \mathrm{C}_{r 2} \mathrm{O}_{7}\right)$ was digested for 2 hours in a $\mathrm{HACH}^{\circledR}$ DRB200 digester block at $150^{\circ} \mathrm{C}$, with a subsequent reading of the absorbance in the HACHL ${ }^{\circledR}$ DR 5000 spectrophotometer at $600 \mathrm{~nm}$. The standard curve for COD analysis was constructed using potassium biftalate. Total nitrogen ( $\mathrm{TN}$ ) was determined by the digestion method with potassium persulfate and sodium hydroxide in a $\mathrm{HACH}^{\circledR}$ DRB200 digestion block for 30 minutes, with readings at $410 \mathrm{~nm}$ in $\mathrm{HACH}^{\circledR}$ DR 5000 Spectrophotometer. Total phosphorus content (TP) was determined by digestion of the sample with sulfuric acid, followed by colorimetric reaction using LABORLAB ${ }^{\circledR}$ kit and spectrophotometer reading at $340 \mathrm{~nm}$.

Maximum specific growth rates $\left(\mu_{X}\right), \operatorname{COD}\left(q_{C O D}\right)$ and $\mathrm{TN}\left(q_{T N}\right)$ consumption were estimated from the profiles of cell concentration $(\mathrm{X}), \mathrm{COD}$ and $\mathrm{N}$, according to equations (1)-(3)

$$
\begin{gathered}
\mu_{X}=\frac{1}{X} \frac{d(X)}{d t}, \\
q_{C O D}=-\frac{1}{X} \frac{d(C O D)}{d t} \\
q_{T N}=-\frac{1}{X} \frac{d(T N)}{d t} .
\end{gathered}
$$

The yields of the substrates (COD, TN and TP) in biomass $\left(Y_{X / S}\right)$ were estimated by the relation of the growth and consumption rates, i.e., by the slope of the biomass curve vs. Substrates (S), according to equation (4)

$$
Y_{X / S}=-\frac{d(X)}{d(S)}
$$

\section{Results and discussion}

The urban wastewaters contain several organic compounds, such as volatile and non-volatile soluble acids, amino acids and carbohydrates, which can be assimilated by microalgae in mixotrophic and heterotrophic cultures (ZHANG et al., 2008). High turbidity of the raw effluents limits the application of photosynthetic microorganisms, suggesting that only strains of microalgae and cyanobacteria with heterotrophic metabolism, which can develop from the nutrients and organic matter available in the medium. Table 1 shows the kinetic variables and the maximum removals of COD, nitrogen and phosphorus in the cultivation of D. subspicatus in domestic effluent from the CCA/UFSCar, which confirm this hypothesis, despite the 
low $\mu \max \left(0.084 \mathrm{~h}^{-1}\right)$. The $\mathrm{C} / \mathrm{N}$ and N/P ratios calculated by the COD, NT and P contents of the wastewater were 1.2 and 21 , respectively. $\mathrm{C} / \mathrm{N}$ ratio in particular would be below the value considered optimal for the growth of these microorganisms, i.e., around 20 (LORENZO, 1995; QUEIROZ; KOETZ, 1997; QUEIROZ et al., 2002). Despite this composition in terms of carbon and nitrogen in the effluent, there was a trend of microbial growth up to 24 hours with biomass concentration maxima around $1000 \mathrm{mg} \mathrm{L}^{-1}$ ( Figure 1). This growth kinetic was similar to Martinéz et al. (2000) in cultures with these same microalgae in domestic effluent. In this research, the authors emphasized the importance of the composition of this effluent and the high N/P ratio in the microbial growth. The differences between the results can be attributed to a higher inoculum and a lower batch time than those used by these authors.

Table 1 - Maximum specific growth rates $\left(\mu_{X}\right)$, COD $\left(q_{C O D}\right)$ and $\mathrm{TN}\left(q_{N T}\right)$ consumption, maximum removal of COD, TN and TP from urban wastewater by D. subspicatus

\begin{tabular}{cc}
\hline Parameter & Value \\
\hline$\mu_{X}\left(h^{-1}\right)$ & $0.084\left(\mathrm{R}^{2}=0.98\right)$ \\
$q_{C O D}\left(h^{-1}\right)$ & $0.029\left(\mathrm{R}^{2}=0.94\right)$ \\
$q_{N T}\left(h^{-1}\right)$ & $0.34\left(\mathrm{R}^{2}=0.95\right)$ \\
E-COD $(\%)$ & $65.75(18$ hours $)$ \\
E-TN $(\%)$ & $60.24(21$ hours $)$ \\
E-TP $(\%)$ & $16.47(24$ hours $)$ \\
\hline
\end{tabular}

$\mu_{X}$ : maximum specific growth rates; $q_{C O D}$ : specific COD consumption rate; $q_{N T}$ : specific TN consumption rate; E - COD: maximum COD removal; $\mathrm{E}$ - TN: maximum TN removal; E - TP: maximum TP removal; $\mathrm{R}^{2}$ : coefficient of correlation from linear fit of growth and COD/TN consumption Source: The authors.

Figure 1 - Biomass profile of D. subspicatus from urban wastewater of CCA/UFSCar

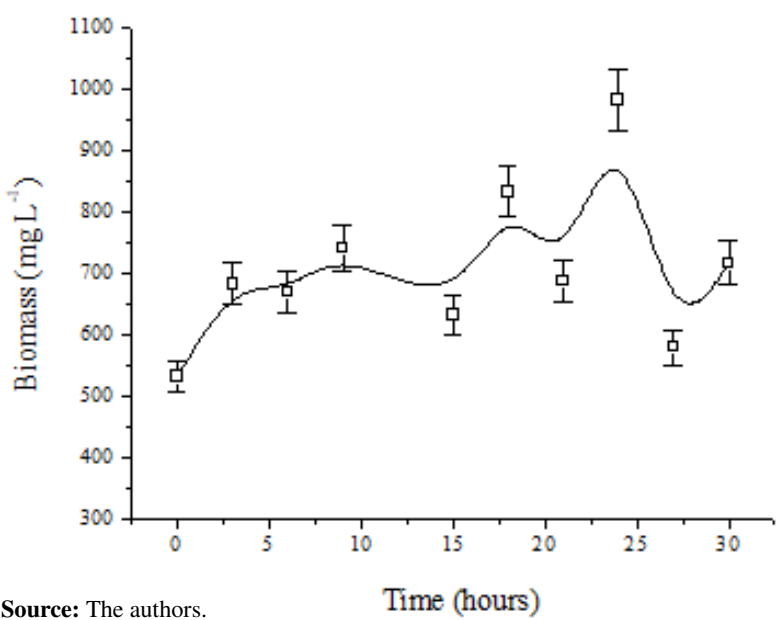

The characteristics of this domestic effluent suggests that it is not feasible to maintain these experiments for more than 30 hours without the incidence and influence of bacterial contamination. Due to the great variability of the effluent tested, the medium sample showed the initial values of COD and NT in the same order of magnitude, making both the amount of organic matter and nitrogen limiting to the microbial growth under these conditions. This is corroborated by the values of the consumption rates of COD (qCOD) and $\mathrm{TN}(\mathrm{qTN})$, which have a $1^{\text {st }}$ order reaction. COD and NT profiles presented in Figure 2 suggest that the cultivation of D. subspicatus in this wastewater is limiting of carbon and nitrogen, and a large part of these constituents is converted into microalgal biomass. The water reuse system presents initial stages of treatment by septic tank, which are responsible for the removal of most of the organic matter. Thus, $\mathrm{C} / \mathrm{N}$ ratio at the inlet of the microalgae tank responsible for nutrient removal tends to be low due to the minor consumption of this nutrient in the previous steps.

In this way, there is the growth of microalgae with high nitrogen removals in the first hours, with the maximum around $60 \%$ for 21 hours-batch. This consumption corresponds to an overall average yield of nitrogen in biomass of $13 \mathrm{mg} \mathrm{mmol}^{-1}$. Considering this batch time, the results suggest that the inlet flow in the microalga tank could be adjusted so that the ideal cell residence-time for nitrogen consumption in 21 hours. In this case, this heterotrophic process differs from microalgae wastewater treatments, which generally use high cell residence-times in ponds and/or open systems. Moreover, the use of a heterotrophic reactor with microalgae from wastewater would combine the removal of nutrients with the generation of useful biomass.

According to Flores and Herrero (1994), various forms of nitrogen can be assimilated by cyanobacteria and microalgae, including some amino acids, which are transported into the cells with the aid of specific proteins called porins (diffusion by facilitated transport). Thus, the characteristics of this effluent explain the nitrogen consumption shown in Figure 2. Even after microalgae cultivation, the nitrogen content remains above $100 \mathrm{mg}^{-1}$, which is interesting since it is intended use this nutrient in the irrigation of agricultural crops, allowing the reuse of this wastewater.

According to the IAC Technical Bulletin (TRANI; TIVELLI; CARRIJO, 2011), is recommended $149 \mathrm{~g}$ TN per hectare of the lettuce crop. This residual nitrogen concentration of the effluent from this pilot experimental station could supply approximately 
80 ha of this crop, considering only this nutrient as the calculation basis for ferti-irrigation.

Figure 2 - COD (०) and TN $(\square)$ profiles during cultivation of D. subspicatus from urban wastewater of CCA/UFSCar

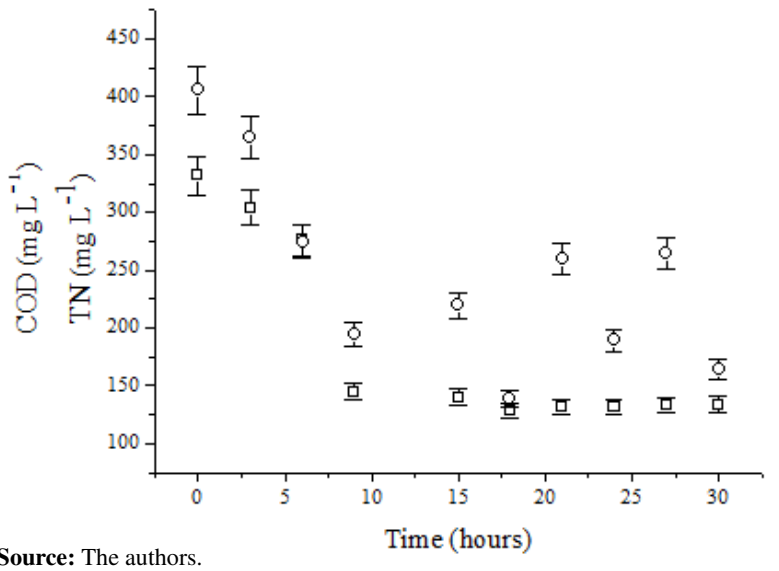

Figure 3 presents a trend of two distinct regions that characterize yield of COD into biomass. For COD concentrations above $250 \mathrm{mg} \mathrm{L}^{-1}$ (in the first hours of microalgae cultivation), there is a high and constant conversion of COD to biomass, indicating that most of the available organic matter is converted by microalgae. However, below $250 \mathrm{mg} \mathrm{L}^{-1}$, yield varies with COD consumption. According to these profiles and considering the conversion of organic matter into biomass as an important process parameter, the batch time of this process could be reduced, with maintenance of maximum yield in the first 15 hours.

Figure 3 - COD and biomass profiles with YX/COD for D. subspicatus from urban effluent of CCA/UFSCar

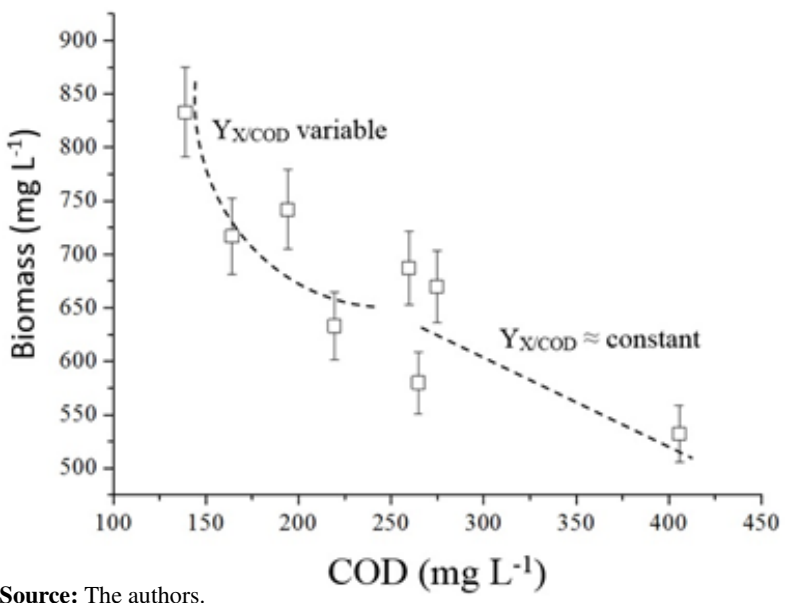

Figure 4 presents the phosphorus and $\mathrm{pH}$ profiles. Although several reports in the literature on the use of cyanobacteria in the removal of phosphorus, the results indicate that these nutrients were not considerably assimi- lated during the experimental period, probably due to the high initial N/P ratio. After 30 hours of sampling, considering the final TN and TP values, the N/P ratio would be reduced by half, which is closer to the ideal microalgae and cyanobacteria cultivation conditions (COLMENARESROLDAN et al., 2012). However, Bastos et al. (2012b) reported phosphorus removals in the order of $92 \%$ from this same wastewater by the cyanobacterium Aphanothece microscopic Nägeli, which suggests the importance of the initial conditions for nutrient removal. Xin et al. (2010) determined the elemental composition of the microalgae Scedesmus sp., with empirical formula biomass of $\mathrm{CH}_{2.48} \mathrm{O}_{1.04} \mathrm{~N}_{0.15} \mathrm{P}_{0.0094}$. According to this estimate, it can be seen that the nitrogen requirement that will be incorporated into the biomass is about 15 times higher than the phosphorus requirements, which suggests the lower removal of this nutrient. On the other hand, these same authors indicate Monod $(\mathrm{kS})$ saturation constants of 12 and $0.28 \mathrm{mg} \mathrm{L}^{-1}$ for nitrogen and phosphorus, respectively, which represent concentrations lower that provided by domestic wastewater, explaining the growth of microalgae under these conditions. Moreover, according reported in the literature for this Desmodesmus, the low removal of phosphorus does not influence nitrogen consumption (ZHANG et al., 2008). However, the minor consumption of phosphorus without direct interference in microalga growth becomes interesting due to the maintenance of this nutrient for irrigation of agricultural crops. For example, the recommended amount of phosphorus as $\mathrm{P}_{2} \mathrm{O}_{5}$ for the lettuce crop is $149 \mathrm{~g} \mathrm{ha}^{-1}$, which would be supplied by this effluent (TRANI; TIVELLI; CARRIJO, 2011).

Figure 4 - Phosphorus (o) and $\mathrm{pH}(\square)$ profiles during cultivation of D. subspicatus from urban wastewater of CCA/UFSCar

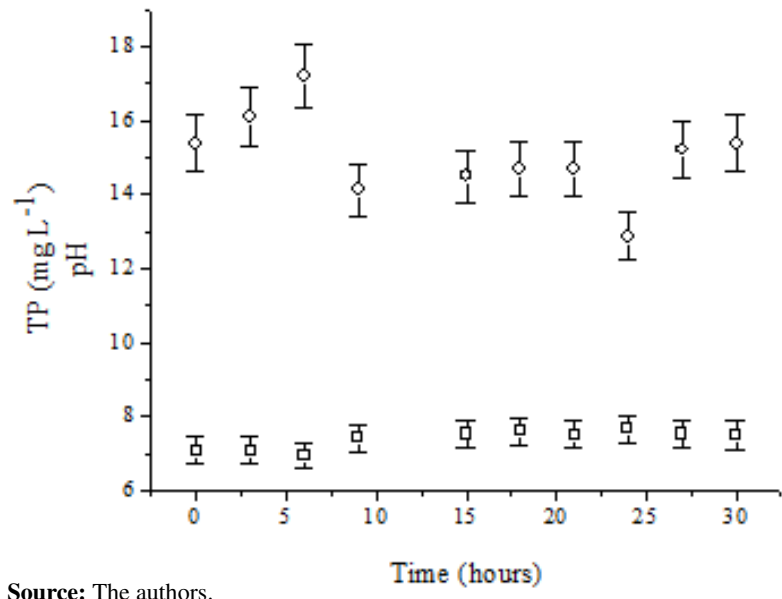

In terms of biomass conversion, the average overall yield of $5.5 \mathrm{~g} \mathrm{mmol}^{-1}$ from phosphorus is much higher than reported by Martínez et al. (2000) by Scenedesmus 
(2.48 $\mathrm{mg} \mu \mathrm{mol}^{-1}$ ). These authors also reported maximum phosphorus removals of $98 \%$, i.e., the slow growth and high accumulation of this nutrient into microalgae biomass. Conventional biological removal of phosphorus from wastewater alternates aerobic and anaerobic conditions, which allow the accumulation of phosphorus by certain bacteria (VON SPERLING, 1997). Considering that the oxygen demand is relatively lower than in conventional wastewater treatment (BASTOS et al., 2011), it would be difficult to form aerobic and anaerobic zones even in heterotrophic culture of these microorganisms.

With respect to $\mathrm{pH}$, this parameter remains practically constant, around 7, despite the heterotrophic culture conditions and the tendency of reduction. Thus, this parameter remained close to an optimum value for growth of these microorganisms, which facilitates the conduction of this process since no adjustment and monitoring or previous stage of neutralization of the evictions is necessary.

\section{Conclusion}

Desmodesmus subspicatus presents a potential growth from urban wastewater of CCA/UFSCar, with partial removal of the nitrogen and organic matter and high yield to biomass. These results allows the final agricultural reuse of the water and suggest that heterotrophic cultivation approach of microalgae is an interesting alternative for the application of these microorganisms in the urban wastewater treatment.

\section{Acknowledgments}

The authors gratefully the São Paulo Research Foundation (FAPESP, Process Number 2010/20081-7) and the National Council for Scientific and Technological Development $(\mathrm{CNPq})$ to financial support of this research.

\section{References}

APHA - American Public Health Association. Standard methods for the examination of water and wastewater. 21 ed. Washington: AWWA/APHA/WEF, 2005. 1368 p.

ASLAN, S; KAPDAN, I.K. Batch kinetics of nitrogen and phosphorus removal from synthetic wastewater by algae. Ecological Engineering, Amsterdam, v. 28, n. 1, p. 64 70, 2006.
BASTOS, R. G.; PAIVA, P.R. ; RIGO, M. ; VEIGA, G. ; QUEIROZ, M. I. . Growth of Aphanothece microscopica Nägeli on exogenous sugars. Bioscience Journal (Online), v. 27, p. 156-161, 2011.

BASTOS, R. G., SOUZA, C. F.; URBANO, V. R.; PULSHEN, A. COD and nutrient removal from urban wastewater by cyanobacteria Aphanothece microscopica Nägeli. In: ALGAL BIOMASS, BIOFUELS AND BIOPRODUCTS, 2012, San Diego, CA. Proceedings [...]. San Diego, CA: Elsevier, 2012b.

BASTOS, R. G.; MATTOS, L. F. A.; DESSIA, V. C.; GOLDEMBERG, S.; SILVA, D. Heterotrophic growth of desmodesmus subspicatus using sugarcane vinasse in batch stirred reactor. In: ALGAL BIOMASS, BIOFUELS AND BIOPRODUCTS, 2012, San Diego, CA. Proceedings [...]. San Diego, CA: Elsevier, 2012a.

BASTOS, R. G.; QUEIROZ, M. I.; ALMEIDA, T. L.; BENERI, R. L.; ALMEIDA, R.V.; PADILHA, M. Remoção de nitrogênio e matéria orgânica do efluente da parboilização do arroz por Aphanothece microscopica Nägeli na ausência de luminosidade. Revista da Engenharia Sanitária e Ambiental, Rio de Janeiro, v. 9, n. 2, p.112 - 116. 2004.

BHATNAGAR, A.; CHINNASAMY, S.; SINGH, M.; DAS, K. C. Renewable biomass production by mixotrophic algae in the presence of various carbon sources and wastewaters. Applied Energy, London, v. 88, n. 10, p. 3425 - 3431, 2011.

COLMENARES-ROLDAN, G.; RENDÓNCASTRILLÓN, L.; RAMÍREZ-CARMONA, M.; VELEZ-SALAZAR, Y. Wastewater treatment by using algae as potential for biodiesel production. . In: ALGAL BIOMASS, BIOFUELS AND BIOPRODUCTS, 2012, San Diego, CA. Proceedings [...]. San Diego, CA: Elsevier, 2012.

DEVI, M. P.; SUBHASH, G. V.; MOHAN, S. V. Heterotrophic cultivation of mixed microalgae for lipid accumulation and wastewater treatment during sequential growth and starvation phases: effect of nutrient supplementation. Renewable Energy, Oxford, v. 43, p. 276 - 283 , 2012.

FLORES, E.; HERRERO, A. Assimilatory nitrogen metabolism and its regulation. In: BRYANT, D. A. The Molecular Biology of Cyanobacteria. Switzerland: Kluwer Academic Plubishers, 1994. p. 409 - 435. 
LORENZO, M. Relação de nutrientes e de fatores ambientais na ocorrência de cianobactéria Aphanothece sp ao redor da cidade de Rio Grande. 1995. Trabalho de Conclusão de Curso (Graduação em Oceanografia) - Fundação Universidade Federal do Rio Grande, Rio Grande do Norte, 1995.

MARTÍNEZ, M. E., SÁNCHEZ, S., JÍMENEZ, J. M., YOUSFIS, F. E.; MUÑOZ, L. Nitrogen and phosphorus removal from urban wastewater by the microalga Scenedesmus obliquus. Bioresource Technology, Essex, v. 73 , n. 3, p. 263 - 272, jul. 2000

MATTOS, L. F. A.; BASTOS, R. G. COD and nitrogen removal from sugarcane vinasse by heterotrophic green algae Desmodesmus sp. Desalination Water Treatment, Hopkinton, MA, v. 57, n. 20, p. 9465 - 9473, mar. 2015.

MENDES, P. E. F.; SOUZA, C. F.; FERREIRA, A. J. D.; MATTOS, L. F. A. Água de reúso na agricultura: implicações agronômicas e ambientais em rabanate (Raphanus sativus L.). In: CONGRESSO BRASILEIRO DE ENGENHARIA AGRÍCOLA (CONBEA), 42, 2013, Fortaleza. Anais [...]. Fortaleza: [s.n.], 2013.

MENDONÇA, T. G.; URBANO, V. R.; BASTOS, R. G., SOUZA, C. F. Efeitos da aplicação de água de reúso no solo cultivado com alface (Lactuca sativa L.). In: CONGRESSO BRASILEIRO DE ENGENHARIA AGRÍCOLA (CONBEA), 42, 2013, Fortaleza. Anais [...]. Fortaleza: [s.n.], 2013.

OLIVEIRA, A. A. S; BASTOS, R. G.; SOUZA, C. F. Adaptation of domestic effluent for agricultural reuse by biological, physical treatment and disinfection by ultraviolet radiation. Ambiente Água,Taubaté, v. 14, n. 2, mar. 2019.

PEREZ-GARCIA, O.; BASHAN, Y.; PUENTE, M. E. Organic carbon supplementation of sterilized municipal wastewater is essential for heterotrophic growth and removing ammonium by the microalga Chlorella vulgaris. Journal of Phycology, [New York], v. 47, n. 1, p. 190 199, feb. 2011.

PEREZ-GARCIA, O.; ESCALANTE, F. M. E.; DEBASHAN, L. E.; BASHAN, Y. Heterotrophic cultures of microalgae: metabolism and potential products. Water Research, Oxford, v. 45, n. 1, p. 11 - 36, jan. 2011.
QUEIROZ, M. I.; BASTOS, R. G.; BENERI, R. L.; ALMEIDA, R. V. Evaluación del crecimiento de la Aphanothece microscopica Nägeli en las aguas residuales de la parbolización del arroz. Revista Información Tecnologica, Chile, v. 13, n. 1, p. $61-65,2002$.

QUEIROZ, M. I.; KOETZ, P. R. Caracterização do efluente da parbolização do arroz. Revista Brasileira de Agrociência, Pelotas, RS, v. 3, n. 3, p. 139 - 143, 1997.

RIPPKA, R.; DERUELLES, J.; WATERBURY, J. B.; HERDMAN, M.; STANIER, R. Y. Generic assignments strain histories and properties of pure cultures of cyanobacteria. Journal of General Microbiology, London, n.111, p. $1-61,1979$

SILVA, M.A.; BARBOSA, G.H.; CODATO, C.B.; MATTOS, L.F.A.; BASTOS, R.G.; KIECKBUSCH, T.G. Heterotrophic growth of green microalgae Desmodesmus subspicatus in ethanol distillation wastewater (vinasse) and lipid extraction with supercritical CO2. Journal of Chemical Technology and Biotechnology, Oxford, v. 92, n. 3, p. 573 - 579, 2017.

TRANI, P. E.; TIVELLI, S. W.; CARRIJO, O. A. Fertirrigação em Hortaliças. 2 ed. Campinas: Instituto Agronômico, 2011. 51 p. (Série Tecnologia APTA. Boletim Técnico IAC, n. 196).

VON SPERLING, M. Lodos ativados. 2. ed. Belo Horizonte: Departamento de Engenharia Sanitária e Ambiental: UFMG, 1997. 428 p. (Princípios do tratamento biológico de águas residuárias; v. 4).

WU, L. F.; CHEN, P. C.; HUANG, A. P.; LEE, C. M. The feasibility of biodiesel production by microalgae using industrial wastewater. Bioresource Technology, Essex, v. 113 , p. $14-18,2012$.

XIN, L.; HONG-YING, H; KE, G.; YING-XUE, S. Effects of different nitrogen and phosphorus concentration of growth uptake, and lipid accumutation of a freshwater microalga Scenedesmus sp. Bioresouce Technology, Essex, v. 101, p. $5494-5500,2010$.

ZHANG, E.; WANG, B.; WANG, Q.; ZHANG, S.; ZHAO, B. Ammonia-nitrogen and orthophosphate removal by immobilized Scenedesmus sp. isolated from municipal wastewater for potential use in tertiary treatment. Bioresource Technology, Essex, v. 99, p. 3787 - 3793, 2008.

Received: Mar. 15, 2018 Accepted: June 04, 2019 